\title{
PENGARUH LEADER-MEMBER EXCHANGE DAN PSYCHOLOGICAL EMPOWERMENT TERHADAP INNOVATIVE WORK BEHAVIOR: REVIEW SISTEMATIK
}

\author{
Nirmala Manindra Dwi Putri ${ }^{1}$, Anwar Ma'ruf ${ }^{2}$, Sutinah $^{3}$ \\ ${ }^{1,2,3}$ Magister Manajemen Sumberdaya Manusia, Pascasarjana Universitas Airlangga \\ e-mail: nirmalamanindra@gmail.com, anwar23@gmail.com, sutinah34@gmail.com
}

\begin{abstract}
Abstrak
Dalam era kompetisi bisnis, implementasi dari perilaku kerja inovatif (innovative work behavior) selalu dibutuhkan untuk menciptakan terobosan untuk meningkatkan produk yang dihasilkan serta menjaga keberlangsungan bisnis itu sendiri. Perilaku kerja inovatif dapat didorong melalui pertukaran pemimpin dan anggotanya (leadermember exchange) dan pemberdayaan psikologis (psychological empowerment). Penelitian ini bertujuan untuk mencari tahu pengaruh leader-member exchange dan psychological empowerment terhadap innovative work behavior. Metode yang digunakan dalam penelitian ini adalah review sistematik literature elektronik dari database Google Scholar. Pencarian dilakukan dengan menggunakan kata kunci "leader-member exchange", "psychological empowerment", dan "innovative work behavior". Seleksi dengan menggunakan kriteria eksklusif kemudian dilakukan untuk mempersempit topik yang diinginkan menjadi pengaruh hubungan antara leadermember exchange dan psychological empowerment terhadap innovative work behavior, sehingga didapatkan dua puluh artikel penelitian yang kemudian digunakan pada review sistematik ini. Hasilnya diketahui bahwa interaksi yang terjadi dalam leader-member exchange yang melibatkan psychological empowerment dapat menimbulkan motivasi intrinsik pada karyawan untuk memunculkan innovative work behavior.
\end{abstract}

Kata kunci : Pemberdayaan psikologis, Perilaku kerja inovatif, Pertukaran pemimpin-anggota.

\begin{abstract}
Business industry has always been required to implement innovative work behaviour in order to create innovation for the improvement of the products and maintaining the sustainability of its business especially in this competitive era. Innovative work behaviour can be encouraged through leader-member exchange interactions and psychological empowerment. This research aimed to find out the influence of leadermember exchange and psychological empowerment towards innovative work behaviour. Method used in this research was systematic e-systematic review from Google Scholar database. A thorough searching of research articles was done with the keywords "innovative work behaviour", "psychological empowerment", and "leader-member exchange". Exclusive criterion selection was then made to narrow it down to the specific topic of the influence of leader-member exchange and psychological empowerment towards innovative work, resulting twenty articles being used in this systematic review. Results shown that the influence of leader-member exchange and psychological empowerment on innovative work behaviour were in the intrinsic motivation it could cause, which in turn could motivate employees to show innovative work behaviour.
\end{abstract}

Keywords : Innovative work behaviour, Leader-member exchange, LMX, Psychological empowerment 


\section{PENDAHULUAN}

Pertumbuhan ekonomi Indonesia mengalami stagnansi selama tiga tahun terakhir yakni hanya mencapai $5,04 \%$ secara kumulatif. Pada tahun 2019 terjadi penurunan pertumbuhan ekonomi sebesar $0,15 \%$ dari periode kuartal III 2018 sebesar 5,17\% menjadi $5,02 \%$. Kondisi ini berdampak buruk bagi perekonomian Indonesia sehingga dibutuhkan peran sektor-sektor pendukung untuk mendorong pertumbuhan ekonomi (Kemenperin, 2019).

Perubahan teknologi dan tingkat kompetisi yang tinggi mendesak munculnya ide dan strategi baru agar unggul dalam persaingan pasar (Carmeli \& Atwater, 2009). Peningkatan kebutuhan untuk berinovasi juga didorong oleh rendahnya tingkat inovasi di Indonesia. Penilaian Global Innovation Index (GII) 2019 menempatkan Indonesia pada urutan 85 dari 129 negara, ditinjau dari aspek perkembangan ilmu pengetahuan dan teknologi, human capital and research, serta creative output. Inovasi dalam sektor industri menjadi salah satu kunci untuk mendorong pertumbuhan dan pembangunan ekonomi nasional (BPS, 2019).

Getz dan Robinson (2003) mengungkapkan bahwa $80 \%$ ide-ide baru dalam berinovasi dimunculkan oleh karyawan. Inovasi individu dalam organisasi disebut dengan perilaku kerja inovatif (innovative work behavior). Akram, Lei, dan Haider (2016) mengungkapkan bahwa perilaku kerja inovatif merupakan landasan fundamental bagi peningkatan kinerja organisasi.

Perilaku kerja inovatif yang dilakukan karyawan di tempat kerja meliputi upaya mengeksplorasi peluang, memunculkan ide, memperjuangkan ide, dan menerapkan ide (de Jong, 2007). Artinya, karyawan berusaha menemukan solusi atas masalah dengan menciptakan gagasan solusi, mencari data pendukung, dan mengimplementasikannya sehingga mampu menghasilkan inovasi dalam bidang produk, pasar, atau struktur organisasi (Orfila-Sintes \& Mattson, 2009). Organisasi dengan perilaku kerja inovatif yang rendah akan mengalami beberapa dampak negatif diantaranya menghambat kinerja organisasi, meningkatkan absensi karyawan, pengunduran diri, buruknya etos kerja karyawan, dan menurunnnya layanan kepada pelanggan (Subramony \& Holtom, 2012). Organisasi dengan demikian perlu berusaha mendorong karyawan untuk memiliki pola pikir inovatif.
Kepemimpinan merupakan salah satu faktor utama yang mempengaruhi perilaku kerja inovatif karyawan. Seorang pemimpin organisasi berperan penting dalam memotivasi, menginspirasi, dan menstimulasi proses kerja karyawan (Turek \& Turek, 2013) melalui relasi yang dibangun untuk meningkatkan kemampuan karyawan (Hammond, dkk., 2011). Atasan dan bawahan perlu menjalin komunikasi dua arah yang dalam teori kepemimpinan disebut dengan pertukaran pemimpin-anggota (leader-member exchange) (Graen \& Uhl-Bien, 1995). Pertukaran sosial berupa ide, kepercayaan, kewajiban, dan kedekatan interpersonal dapat timbul dalam hubungan leader-member exchange (Liden \& Maslyn, 1998). Penelitian Anshari dan kawan-kawan (2018) dan Alsughayir (2017) menunjukkan bahwa kualitas leader-member exchange berpengaruh signifikan terhadap perilaku kerja inovatif karyawan.

Faktor penting selain leader-member exchange, yang juga mempengaruhi perilaku kerja inovatif adalah psychological empowerment atau pemberdayaan psikologis. Spreitzer (2011) menjelaskan bahwa pemberdayaan psikologis bertujuan untuk memberikan daya dan kendali kepada individu sehingga ia merasa mampu menyelesaikan pekerjaannya. Karyawan yang memperoleh pemberdayaan secara psikologis akan merasa lebih percaya diri dalam berpikir kreatif, bertindak proaktif, berlaku inisiatif dan mampu bekerja secara independen. Kapasitas karyawan semakin meningkat seiring dengan meningkatnya motivasi dalam berinovasi karena merasa lebih banyak memperoleh ide dan inspirasi. Amabile (1988) menjelaskan bahwa pemberdayaan psikologis membuat karyawan merasa memiliki kekuatan lebih daripada yang lain untuk melakukan sesuatu yang baru.

Paparan di atas menjadi dasar penelitian ini untuk menggambarkan dinamika psikologis bagaimana pengaruh leadermember exchange dan pemberdayaan psikologis terhadap perilaku kerja inovatif.

\section{METODE}

Jenis Penelitian ini menggunakan metode review sistematis terhadap literatur elektronik pada database Google Scholar. Peneliti menggunakan kata kunci "leadermember exchange", "psychological empowerment", dan "innovative work behavior 
pada artikel dengan topik tersebut yang berasal dari sumber buku elektronik maupun jurnal penelitian. Penelitian ini tidak membatasi jangkauan waktu, jenis publikasi, dan disiplin ilmu tertentu. Peneliti kemudian melakukan seleksi terhadap artikel-artikel yang dianggap tidak mencakup topik mengenai pengaruh hubungan antara leader-member exhcange dan psychological empowerment terhadap innovative work. Hasilnya didapatkan 20 artikel yang digunakan dalam review sistematik ini.

\section{HASIL DAN PEMBAHASAN}

\section{A. Work Innovative Behavior}

Perilaku kerja inovatif adalah perilaku individu yang disengaja untuk pengenalan dan aplikasi, dalam sebuah peran, kelompok atau organisasi dari ide, proses, produk atau prosedur, merupakan suatu hal yang baru bagi unit terkait, dirancang untuk secara signifikan menguntungkan individu, kelompok, organisasi atau masyarakat yang lebih luas (West \& Farr, 1990). Pengertian perilaku kerja inovatif adalah proses memunculkan, mengenalkan dan menerapkan gagasan-gagasan baru demi mendapatkan manfaat bagi organisasi atau kelompok (Janssen, 2000). Gagasan baru tersebut dapat berupa pembaruan teknologi, produk, layanan, atau metode kerja (Kleysen \& Street, 2001).

Pendapat de Jong (2007) menyatakan bahwa perilaku kerja inovatif adalah rangkaian proses melahirkan dan menerapkan ide, produk, proses, maupun prosedur baru yang bermanfaat untuk organisasi. Relevansi perilaku kerja inovatif dalam konteks organisasi adalah pada usaha yang menghasilkan keuntungan bagi organisasi atau perusahaan. Kreativitas karyawan, menurut de Jong dan Hartog (2010) berhubungan erat dengan perilaku kerja inovatif yang merupakan tahap awal munculnya inovasi dalam bidang pemecahan masalah atau solusi atas suatu permasalahan.

Empat dimensi perilaku kerja inovatif secara konseptual dirumuskan oleh de Jong (2007) yakni eksplorasi peluang, pemunculan ide, memperjuangkan ide, dan penerapan ide. Inovasi diawali dari penemuan kesenjangan antara potensi dan kinerja nyata. Peluang memunculkan ide-ide solutif baru untuk memecahkan masalah. Gagasan yang diusulkan membutuhkan dukungan dari pihak lain untuk mendorong negosiasi. Selanjutnya, ide yang dikembangkan diimplementasikan demi mencapai pemecahan masalah. De Jong (2007) juga menambahkan empat anteseden perilaku kerja inovatif, antara lain pada tingkat individu, kelompok, organisasi, dan faktor lingkungan. Faktor lingkungan dapat berupa kompetisi (Ong, Wan, \& Chang, 2003), dan tipe organisasi (Hill \& Johnson, 2003)

\section{B. Leader-member Exchange}

Konsep teori leader-member exchange berfokus pada nilai-nilai timbal balik antara pimpinan dengan karyawan (Graen \& UhlBien, 1995). Efektivitas kepemimpinan ditandai dengan hubungan atasan dan bawahan yang menunjukkan kedewasaan dan kebermanfaatan bagi kedua pihak. Leadermember exchange disertai dengan perasaan saling menghormati, menyenangi, dan loyalitas yang tinggi. Atasan memberikan bawahan kesempatan, dukungan, dan pendampingan untuk berkembang (Erdogan \& Bauer, 2015). Perilaku atasan tersebut akan memotivasi bawahan untuk memberikan timbal balik yang lebih besar kepada atasan.

Liden dan Maslyn (1998) menjelaskan empat dimensi dalam konsep leader-member exchange meliputi: a) Afeksi, berhubungan dengan ketertarikan antarindividu yang berlanjut pada keakraban interpersonal dan emosional; b) Loyalitas, ditandai dengan kesetiaan dan dukungan satu sama lain secara konsisten pada setiap waktu dan kondisi; c) Kontribusi, merujuk pada kualitas kinerja bawahan dalam mengerjakan tugas dari atasan. Semakin tinggi kontribusi bawahan, maka pemimpin akan semakin terkesan, d) Penghargaan profesionalitas berkaitan dengan pandangan karyawan atas citra dan prestasi atasan di lingkungan internal maupun eksternal organisasi.

Leader-member exchange berdampak positif bagi organisasi, antara lain menjadikan tingkat turnover menjadi rendah, meningkatkan komitmen organisasi, meningkatkan kepuasan kerja karyawan dan juga organizational citizenship behavior (Walumbwa, dkk., 2011; Volmer, dkk., 2011). Leader-member exchange yang positif juga dapat mempengaruhi perasaan karyawan menjadi positif. Perasaan positif karyawan dianggap dapat meningkatkan kreativitas (Northouse, 2013). Pola leader-member exchange yang negatif, sebaliknya, dapat membawa dampak negatif bagi kinerja dalam organisasi. Bentuk leader-member exchange yang negatif diantaranya hubungan dengan atasan yang terlalu dekat dapat memicu karyawan bersikap meremehkan pekerjaan (Rofcanin \& Mehtap, 2010). Dengan demikian, dibutuhkan kendali atas kualitas leader-member exchange antara atasan dan bawahan. 


\section{Pemberdayaan Psikologis}

Pemberdayaan psikologis berarti pelimpahan wewenang dan tanggung jawab kepada karyawan dalam pengambilan keputusan dan segala aktivitas yang terkait (Garrett-Jones \& Fernando, 2013). Spreitzer (1998 dalam Jin-Liang \& Hai-Zhen, 2012) mendefinisikan pemberdayaan psikologis sebagai motivasi intrinsik individu dalam melaksanakan peran kerjanya yang tercermin dari makna, kompetensi, penentuan diri, dan dampak. Pemberdayaan psikologis di tempat kerja akan terbentuk oleh interaksi antara individu dengan lingkungan kerjanya (Conger \& Kanungo, dkk., dalam Lee, Weaver, \& Hrostowski 2011). Maka, pemberdayaan psikologis dilihat sebagai seperangkat kognisi yang memperkuat keyakinan karyawan bahwa mereka kompeten dalam pekerjaan, mampu bertindak efektif dan memiliki kendali atas keputusan mereka (Lee, Weaver, \& Hrostowski, 2011).

Karyawan yang diberdayakan secara psikologis menjadi semakin yakin akan kompetensi dan keahliannya untuk mengerjakan tugas-tugasnya (Meyerson \& Kline, 2008). Mereka lebih puas dengan hasil kerja mereka, berkomitmen tinggi pada organisasi, kemungkinan pengunduran diri rendah, dan menunjukkan kinerja yang lebih positif. Karyawan dengan demikian akan mampu menentukan nasib sendiri secara otonom dan independen, dibentuk oleh interaksi lingkungan dengan memperhatian aspek makna kerja, kompetensi, dampak yang ditimbulkan kepada organisasi atau perusahaan, dan prinsip kemandirian.

Spreitzer (dalam Jin-Liang \& Hai-Zhen, 2012) lebih lanjut menjelaskan bahwa dimensi makna dalam pemberdayaan psikologis mengacu pada kesesuai antara tujuan kerja dengan perilaku di tingkat individu. Dimensi kompetensi berarti keyakinan individu pada kemampuannya dalam melaksanakan kerja dan menghasilkan capaian yang bernilai. Dimensi penentuan diri atau self-determination yakni pandangan individu terhadap lembaga dalam memulai dan menentukan tindakan. Dimensi dampak melibatkan keyakinan individu akan hasil yang dia berikan pada tempat kerja.

Terdapat dua faktor yang memengaruhi pemberdayaan psikologis, yakni faktor individu dan organisasi (Lee \& Koh, 2001 dalam Koesindratmono \& Septarini, 2011). Faktor individu berkaitan dengan karakteristik pribadi karyawan meliputi jenis kelamin, tingkat pendidikan, jabatan, dan masa kerja terhadap kondisi fisik dan nonfisik di tempat kerja. Sedangkan faktor organisasi yakni mencakup rentang kendali, ketidakjelasan peran, akses informasi dan sumber daya, dukungan sosial serta iklim kerja.

\section{PENUTUP}

Teori kepemimpinan leader-member exchange menekankan pada nilai-nilai timbal balik antara pimpinan dengan karyawan (Graen \& Uhl-Bien, 1995). Konsep leadermember exchange mendeskripsikan terjadi pertukaran sumber daya dan dukungan emosional dari atasan ke bawahan dan sebaliknya (Kang \& Steward, 2007). Setiap pemimpin dan karyawan tentu saja mengembangkan kualitas hubungan kerja yang berbeda-beda yang dipengaruhi diantaranya oleh relasi formal kontrak kerja hingga kedekatan interpersonal.

Kualitas leader-member exchange yang tinggi dilandaskan pada pendekatan berbasis hubungan. Dalam konteks ini, aspek-aspek afektif sangat berpengaruh terhadap kualitas leader-member exchange yang terbangun. Aspek-aspek afektif tersebut diantaranya adalah rasa saling percaya, menghormati, dan tanggung jawab dalam perusahaan. Hubungan kepemimpinan dinilai efektif jika telah mencapai hubungan yang dewasa dan bersifat mutual satu sama lain (Graen \& Uhl-Bien, 1995). Pimpinan dalam hubungan yang demikian akan memberikan kesempatan bagi karyawan untuk berkembang, sebaliknya karyawan akan termotivasi untuk mengerjakan tugas melebihi target secara sukarela.

Proses relasi pimpinan dan karyawan seperti di atas menunjukkan terjadinya pemberdayaan psikologis bagi karyawan. Pemberdayaan psikologis, sebagaimana leader-member exchange, dalam prosesnya bekerja dengan memotivasi karyawan. Pemberdayaan psikologis menumbuhkan keyakinan pada diri karyawan bahwa ia mampu melaksanakan penugasan kerja yang diberikan. Motivasi intrinsik yang muncul tersebut tercermin ke dalam empat aspek kognisi yakni makna, kompetensi, penentuan diri, dan dampak bagi organisasi atau perusahaan. Karyawan yang mengalami pemberdayaan psikologis akan mampu mengambil keputusan secara mandiri dan cenderung mampu bekerja secara otonom.

Perilaku yang dapat muncul dari adanya hubungan leader-member exchange dan psychological empowerment adalah perilaku kerja inovatif, yakni tindakan secara sengaja yang dilakukan untuk menghasilkan sebuah inovasi. Sujiwo (2014) menyatakan bahwa perilaku kerja inovatif adalah proses merancang dan menerapkan ide sehingga 
tercipta produk, jasa, proses bisnis, metode, dan kebijakan baru. Proses ini mengubah sikap yang tradisional menjadi modern atau maju (Purba, 2009).

De Jong dan Hartog (2010) mengungkapkan bahwa perilaku kerja inovatif yang tinggi akan menghasilkan inovasi organisasi yang juga tinggi. Perilaku inovasi ditentukan oleh kemampuan perusahaan menghilangkan hambatan dalam berinovasi, sedangkan sumber ide inovasi dapat berasal dari permintaan konsumen, kompetitor, kompetisi atau visi baru perusahaan (Blumentritt \& Danis, 2006). Perilaku kerja inovatif perlu diterapkan untuk mencapai hasil dan keuntungan maksimal bagi perusahaan.

Kajian konseptual antara leader-member exchange dan pemberdayaan psikologis dalam kaitannya dengan perilaku kerja inovatif dapat ditarik kesimpulan sebagai berikut: pertama, perilaku kerja inovatif merupakan aspek penting bagi keberlangsungan dan kesuksesan perusahaan. Kedua, perilaku kerja inovatif dipengaruhi oleh kepemimpinan leader-member exchange dan pemberdayaan psikologis. Atasan dan bawahan perlu mengembangkan hubungan timbal balik untuk menumbuhkan relasi yang saling mendukung dalam berinovasi. Pemberdayaan psikologis juga penting dilakukan untuk menumbuhkan motivasi intrinsik dalam berperilaku inovatif bagi karyawan.

\section{DAFTAR PUSTAKA}

Sujiwo. 2014. "Perubahan Sosial Akibat Perkembangan Usahatani Tebu (Studi Kasus Di Dusun Sumbul Desa Klampok Kecamatan Singosari Kabupaten Malang)." Universitas Brawijaya.

Akram, T., S. Lei, dan M. J. Haider. 2016. "The Impact of Relational Leadership on Employee Innovative Work Behavior in IT Industry of China." Arab Economic and Business Journal 11(2): 153-61.

Alsughayir, A. 2017. "The Effect of Leader-Member Exchange on Innovative Work Behavior in the Saudi Hospitality." International Journal of Business and Management 12(6).

Amabile, T.M., 1988. A model of creativity and innovation in organizations. Research in organizational behavior, 10(1), pp.123-167.

Anshari, dkk. 2018. Pengaruh Leader Member Exchange (LMX) dan Organizational Citizenship Behavior (OCB) Terhadap Innovative Work Behavior (IWB) untuk
Meningkatkan Kinerja Organisasi: Studi pada PT. (Persero) Angkasa Pura I Bandar Udara Internasional Hasanuddin. Jurnal Bisnis, Manajemen dan Informatika. 14(3), 217-227

Blumentritt, T. and Danis, W.M., 2006. Business strategy types and innovative practices. Journal of Managerial Issues, pp.274-291.

BPS. 2019. Badan Pusat Statistik. Retrieved from Badan Pusat Statistik: https://www.bps.go.id/indikator/indikator/list / sdgs 9/

Carmeli, A., dan L. Atwater. 2009. "Leader-Member Exchange, Feelings of Energy, and Involvement in Creative Work." The Leadership Quarterly 20(3): 264-73.

de Jong, J., dan Den Hartog. 2010. "Measurement and Validation." Den Hartog.

de Jong, J.P.J. 2007. "Individual Innovation: The Connection between Leadership and Employee's Innovative Work Behavior."

Bauer, T.N. and Erdogan, B. eds., 2015. The Oxford handbook of leader-member exchange. Oxford university press.

Garrett-Jones, S. and Fernando, M., 2013. THE ROLE OF CAREER ANCHORS AND PSYCHOLOGICAL EMPOWERMENT IN PREDICTING JOB SATISFACTION IN THE INDONESIAN PUBLIC HIGHER EDUCATION. Journal of Knowledge \& Human Resource Management, 5(11).

Graen, G.B. and Uhl-Bien, M., 1995. Relationshipbased approach to leadership: Development of leader-member exchange (LMX) theory of leadership over 25 years: Applying a multilevel multi-domain perspective.

Getz, I., dan A. G. Robinson. 2003. "Innovate or Die: Is That a Fact?" Creativity and Innovation Management 12(3): 130-36.

Hammond, M. M. et al. 2011. "Predictors of Individual Level of Innovation at Work: A Meta Analysis." Psychology of Aesthetics, Creativity, and the Arts 5(1): 90-103.

Hill, R. and Johnson, L.W., 2003. When creativity is a must: professional 'applied creative'services. Creativity and innovation management, 12(4), pp.221-229. 
Janssen, O. 2000. "Job Demands, Perception of Effort-Rewards Fairness and Innovative Work Behavior." Journal of Occupational Organization Psychology.

Jin-Liang, W., dan Hai-Zhen. 2012. "The Influences of Psychological Empowerment on Work Attitude and Behavior in Chinese Organizations." African Journal of Business Management 6(30): 8938.

Kang, D.S. and Stewart, J., 2007. Leader-member exchange (LMX) theory of leadership and HRD. Leadership \& Organization Development Journal.

Kemenperin. 2019. Kemenperin: Analisis Perkembangan Sektor Industri. Retrieved from Kementerian Perindustrian Republik Indonesia: https://kemenperin.go.id/kinerjaindustri

Kleysen, R. F., dan C. T. Street. 2001. "Toward a Multi-dimensional Measure of Individual Innovative Behavior." Journal of intellectual Capital.

Koesindratmono, F. and Septarini, B.G., 2011. Hubungan antara masa kerja dengan pemberdayaan psikologis pada karyawan PT. Perkebunan Nusantara $X$ (Persero). Insan, 13(1), pp.50-57.

Lee, J., Weaver, C. and Hrostowski, S., 2011, December. Psychological empowerment and child welfare worker outcomes: A path analysis. In Child \& Youth Care Forum (Vol. 40, No. 6, pp. 479-497). Springer US.

Liden, R. C., dan J. M. Maslyn. 1998. "Multidimensionality of Leader Member Exchange: An Empirical Assessment through Scale Development." Journal of Management.

Meyerson, S.L. and Kline, T.J., 2008. Psychological and environmental empowerment: Antecedents and consequences. Leadership \& Organization Development Journal.

Northouse, P. G. 2013, Leadership: theory and practice, 6th ed., London: Sage Publication.

Ong, C.H., Wan, D. and Chng, S.H. (2003), "Factors affecting individual innovation: an examination within a Japanese subsidiary in Singapore", Technovation, Vol. 23 No. 7, pp. 617-631.
Orfila-Sintes, F., dan J. Mattson. 2009. "Innovation Behavior in the Hotel Industry." Omega 37(2): 380-94.

Purba, S. 2009. Pengaruh Budaya Organisasi, Modal Intelektual, dan Perilaku

Kerja Inovatif terhadap Kinerja Pemimpin Jurusan di Universitas Negeri Medan. Jurnal Bisnis dan Ekonomi. 13(2), h: 150-167.

Rofcanin, Y. and Mehtap, Ö., 2010. Implications of Leader-Member Exchange Relationship (LMX) Theory and Transformational Leadership Dimensions on Subordinate Citizenship Behavior: An Empirical Paper from Turkey with Services Industry Focus. International Journal of Global Business, 3(1).

Spreitzer, G. M. 1998. "Psychological Empowerment in the Workplace: Dimensions, Measurements and Validation." Academy of Management Journal 3: 144266.

Subramony, M., dan B. C. Holtom. 2012. "The Long-Term Influence of Service Employee Attrition on Customer Outcomes and Profits." Journal of Service Research 15(4): 460-73.

Turek, A. W., dan D. Turek. 2013. "Innovativeness in Organization: The Role of LMX and Organizational Justice, the Case of Poland." International Journal of Synergy and Research 2(1): 41-55.

Volmer, J., Spurk, D. and Niessen, C., 2012. Leader-member exchange (LMX), job autonomy, and creative work involvement. The Leadership Quarterly, 23(3), pp.456465.

Walumbwa, F.O., Cropanzano, R. and Goldman, B.M., 2011. How leader-member exchange influences effective work behaviors: Social exchange and internal-external efficacy perspectives. Personnel Psychology, 64(3), pp.739-770.

West, M.A. and Farr, J.L. eds., 1990. Innovation and Creativity at Work: Psycological and Organizational Strategies. John Wiley. 